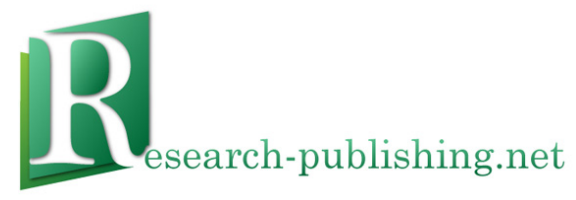

Published by Research-publishing.net

Dublin, Ireland; Voillans, France

info@research-publishing.net

(C) 2013 by Research-publishing.net

Research-publishing.net is a not-for-profit association

Case Studies of Openness in the Language Classroom

Edited by Ana Beaven, Anna Comas-Quinn and Barbara Sawhill

The moral right of the authors has been asserted

All articles in this book are licensed under a Creative Commons Attribution-Noncommercial-No Derivative Works 3.0 Unported License. You are free to share, copy, distribute and transmit the work under the following conditions:

- Attribution: You must attribute the work in the manner specified by the publisher.

- Noncommercial: You may not use this work for commercial purposes.

- No Derivative Works: You may not alter, transform, or build upon this work.

Research-publishing.net has no responsibility for the persistence or accuracy of URLs for external or third-party Internet websites referred to in this publication, and does not guarantee that any content on such websites is, or will remain, accurate or appropriate. Moreover, Research-publishing.net does not take any responsibility for the content of the pages written by the authors of this book. The authors have recognised that the work described was not published before (except in the form of an abstract or as part of a published lecture, or thesis), or that it is not under consideration for publication elsewhere. While the advice and information in this book are believed to be true and accurate on the date of its going to press, neither the authors, the editors, nor the publisher can accept any legal responsibility for any errors or omissions that may be made. The publisher makes no warranty, expressed or implied, with respect to the material contained herein.

Trademark notice: Product or corporate names may be trademarks or registered trademarks, and are used only for identification and explanation without intent to infringe.

Typeset by Research-publishing.net

Cover design: (C) Raphaël Savina (raphael@savina.net)

Fonts used are licensed under a SIL Open Font License

ISBN13: 978-1-908416-09-4 (Paperback, Print on Demand, Lulu.com)

ISBN13: 978-1-908416-10-0 (Ebook, PDF file, Open Access, Research-publishing.net)

ISBN13: 978-1-908416-11-7 (Ebook, Kindle Edition, Amazon Media EU S.à r.1.)

British Library Cataloguing-in-Publication Data.

A cataloguing record for this book is available from the British Library.

Bibliothèque Nationale de France - Dépôt légal: septembre 2013. 


\title{
QThe Community Café: Open Practice with Community-based Language Teachers
}

\author{
Kate Borthwick ${ }^{1}$ and Alison Dickens ${ }^{2}$
}

Abstract

$\mathrm{T}$ his case study describes the work of the Community Café project, which ran from 2010-2011. The project's aim was to foster a community of open practice amongst community-based language teachers by encouraging them to create and publish open educational resources related to their teaching, on an open community repository. The project aimed to address the scarcity of up-to-date, online resources for community languages; the lack of training for Community-based teachers in ICT or innovative pedagogy, and the isolated nature of working in informal, community-based settings. This study considers and outlines the practical steps which were taken to set up the project and engage the community group, who were new to open educational resources and open practice. It describes the mix of informal meetings and formal teacher training employed by the project, and also the issues that need to be considered when reaching out to an ethnically diverse community group. It also gives practical examples of how teachers engaged with project tasks and open educational practice. It concludes that open working has the potential to have a significant impact on the professional lives of community-based language teachers, but that such teachers need time to absorb and embed new knowledge effectively.

Keywords: open educational resources, community languages, professional development, open educational practice, repositories, teaching.

1. Centre for Languages, Linguistics and Area Studies, University of Southampton, UK; K.Borthwick@soton.ac.uk

2. Centre for Languages, Linguistics and Area Studies, University of Southampton, UK; A.M.Dickens@soton.ac.uk

How to cite this chapter: Borthwick, K., \& Dickens, A. (2013). The Community Café: Open Practice with Community-based Language Teachers. In A. Beaven, A. Comas-Quinn, \& B. Sawhill (Eds), Case Studies of Openness in the Language Classroom (pp. 96-109). (O) Research-publishing.net. 


\section{Context}

This case study describes the work of the UK JISC-funded Community Café project, which ran from 2010-2011 (JISC is the Joint Information Systems Committee, a charity which supports technology in education). This project was a collaboration between the University of Southampton, Southampton City Council, and Manchester Metropolitan University, and its aim was to foster a community of open practice amongst community-based language teachers by encouraging them to create and publish open educational resources related to their teaching, on an open community repository.

Community languages are "...languages spoken by members of minority groups or communities within a majority language context" (CILT, The National Centre for Languages). Such languages are often taught 'out-ofhours': in evenings and at weekends in supplementary schools. The teachers of these languages are frequently volunteers and either receive no remuneration or are paid a low hourly rate by local government authorities. They often have no formal teacher training but are native speakers of the languages they teach, and are motivated by enthusiasm, a love of their language and culture, and a desire for the young people in their community to maintain language skills.

Most teach in addition to maintaining full-time jobs or family commitments, and have limited access to on-going training or resources, and limited time for preparation. Yet they face challenging teaching environments, typically having to deal with diverse class sizes, as well as diverse age ranges and abilities frequently within a single class. There is often a lack of appropriate resources for the language that they teach and so most teachers are reliant on creating their own materials.

In the Southampton area, a wide range of community languages are spoken, including Polish, Bengali, Afghan Farsi, Italian and Chinese. Many of these languages are taught to GCSE and A level (UK public examinations taken at the age of 16 and 18 respectively) and pupils range from small children to adult learners. Community-based language teaching within Southampton is 
coordinated by the City Council, who apportions a small amount of funding towards maintaining a network of community-based language teachers. This funding does not include training or resource development.

The Centre for Languages, Linguistics and Area Studies (LLAS), based at the University of Southampton, have been working with language teachers in higher education to explore the benefits and challenges of OEP for several years, and LLAS maintains an open community repository called LanguageBox. The authors identified OEP and publication of OERs as having potential as low-cost, self-sustaining initiatives which could improve the professional lives of community-based language teachers and address many of the challenging issues which they face. Community-based language teachers often do not have access to the tools, knowledge and experience available in mainstream sectors of education. The Community Café project would seek to bridge this gap.

\section{Intended outcomes}

The project initially set out to collect and co-create a suite of digital resources for community language teaching and learning and to publish them as open content on a community website. This would increase the pool of suitable, up-to-date, digital content available to teachers and learners. However, we had other key aims:

- to build a self-managed community-based group (online and offline) to support people engaged in teaching and learning the range of community languages available locally in Southampton;

- to improve the pedagogy of existing materials and methods through peer review and discussion, and encourage general reflective practice;

- to provide bespoke training in using, creating, publishing and sharing digital content; 
- to contribute to the enhancement of the profile and provision of community language learning through adding resources to an online repository hosting a wide range of language resources used in all UK education sectors;

- to open up connections and strengthen existing relationships between academic departments and the local community (both in Southampton and in other geographical locations taking part in the project).

Our intention was to use the publication of open educational resources to offer professional development opportunities to community-based teachers and to encourage enhanced practice through sharing work within a community of peers. The ethos of open working and the 'OER movement' is one of collegiality and sharing across traditional boundaries and we felt that this was highly relevant to teachers working in isolation, outside of mainstream educational settings. It is satisfying and rewarding to share ideas with and learn from colleagues; however, community languages teachers rarely have the opportunity to meet each other. An online community enables networking and sharing to happen within a professional space that is flexible and accommodating and can be accessed at any time and from any location.

The authors used the LLAS community repository, the LanguageBox, as the online space for sharing resources. This site has a social networking aspect and allows for the creation of personal profiles, the addition of comments to resources, emails to resource-creators via the system, and is appealing and easy to use. It already hosts a wide range of resources contributed by teachers from all sectors of education in a range of languages, and could therefore offer our community language teacher group a voice within a wider community of practice, and exposure to different types of resources and ideas.

In this way, the project intended to bring the knowledge, experience, tools and equipment available in the HE sector to assist community-based teachers in improving their practice. Offline (face-to-face) training in the use of technology for teaching and in creating OERs would be essential in order for our teachers to access this knowledge and experience, and the contacts and organisational 
networks of Southampton City Council would also be essential in attracting teachers to the project and maintaining communications with them.

\section{Nuts and bolts}

\subsection{Communications}

The project team was fortunate in being able to use the existing Community Languages support network, coordinated by Southampton City Council, to introduce and recruit teachers to the project. The council officer who ran the network was personally acquainted with all of the teachers, and used every means available to make contact with them (e.g. email, fax, telephone, letter). This range of communication methods was essential as it could accommodate different levels of English language knowledge, and different preferences for communication with the outside world. The use of an existing contact and network was crucial in recruiting and then supporting teachers throughout the project.

\subsection{Informal, 'café' meetings}

The project proceeded with a mixture of informal, café-style meetings and more formal training sessions. The idea behind the Café meetings was that they would provide a forum for 'offline' discussion and would complement the workshops offering training in the use of technology for teaching and sharing. The Café sessions were intentionally informal and user-centred in nature, to enable participants to feel comfortable, to encourage conversations across language groupings, to build confidence in creating digital resources and in using English to describe teaching methods and resources, and to overcome any reticence in sharing ideas/practices. Meetings always featured lots of tea/coffee drinking and cake consumption (carrot cake being a particular favourite).

Café sessions were held at a local school in Southampton, which is the usual venue for meetings of the Community Languages Network. Meetings were 
necessarily held 'out-of-hours' because this is the only time that the teachers were available. Our initial intention was to use a more laid-back local, a public venue such as a café or a library, but participants were clear in their preference for a familiar location.

The first session was designed with the idea of getting teachers to join the project, but also to encourage them to have input into the shape of future meetings. The project team were keen that participants should feel a sense of ownership in the project, and that activities should be directly relevant and responsive to their needs as teachers. We felt that this would increase the likelihood for success, as well as increasing the chances of future sustainability for teacher engagement with open practice and OERs. Subsequent meetings were held every month, on a Tuesday evening.

The structure of each café session was flexible but usually revolved around discussion and practice sharing. Meetings were led by members of the project team, who would typically introduce a theme (e.g. 'using interactive materials in teaching') and encourage participants to mix with new acquaintances crosslanguage groupings. The themes covered in cafe meetings were chosen to complement the training workshops and to prepare participants for the practical sessions. This ensured that pedagogical ideas, language issues, and concepts around open working could be worked through in advance, enabling trainers to focus on practical issues during workshops.

\subsection{Training sessions}

Six evening workshops in the use of technology in language teaching ran during the course of the project. They were held at the University of Southampton and were facilitated either by members of LLAS or by commissioned trainers. Topics were negotiated with tutors at the outset of the project and were on these areas: using and sharing material on the LanguageBox, creating podcasts, using Powerpoint for language teaching, creating online activities using $\mathrm{Hot}$ Potatoes - part 1, creating online activities using Hot Potatoes - part 2, and tips for teaching diverse groups. There were also several unstructured sessions 
during which participants worked on material of their choice. The workshops were practical and offered participants hands-on experience with tools and software.

\section{In practice}

Workshop sessions were structured around an achievable task so that each participant was able to complete a digital item by the end of the workshop. The reasoning behind this design was that it was intended to encourage a sense of achievement and empowerment in the group. Workshop tasks were kept consciously simple in order to accommodate all levels of IT-literacy or English language issues. However, tasks were flexible enough to allow for adaptation and extension by those who felt more confident in their resource-creation.

The following examples illustrate how two Community Café themes worked in practice.

\subsection{Podcasting/creating audio recordings for teaching}

The café session preceding the practical workshop prepared the participants to create their own online audio recordings to use in class. The session encouraged discussion around why creating audio recordings could be useful; how audio material can be presented, and some basic principles related to creating audio recordings. It concluded with participants creating a plan and script for a short audio recording. Figure 1, Figure 2 and Figure 3 below show an extract from the facilitator's notes and the plans made by a teacher of Punjabi for an audio recording on the topic of 'summer'.

During the practical workshop which followed this café session, participants learned how to use the free audio recording software, Audacity, and then went on to create their own recordings. Figure 4 shows the final online open recording on the topic of 'summer', in Punjabi. This file on the LanguageBox includes the plans illustrated above. 
Figure 1. An extract from the Facilitator's notes for the café session on podcasting http://languagebox.ac.uk/1854/

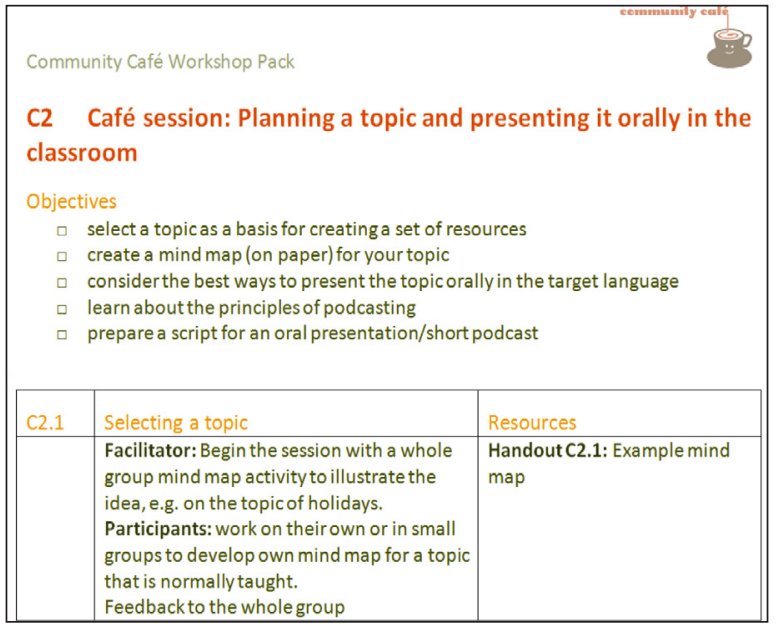

Figure 2. The script for the audio recording in Punjabi, on the topic of 'summer' http://languagebox.ac.uk/1779/

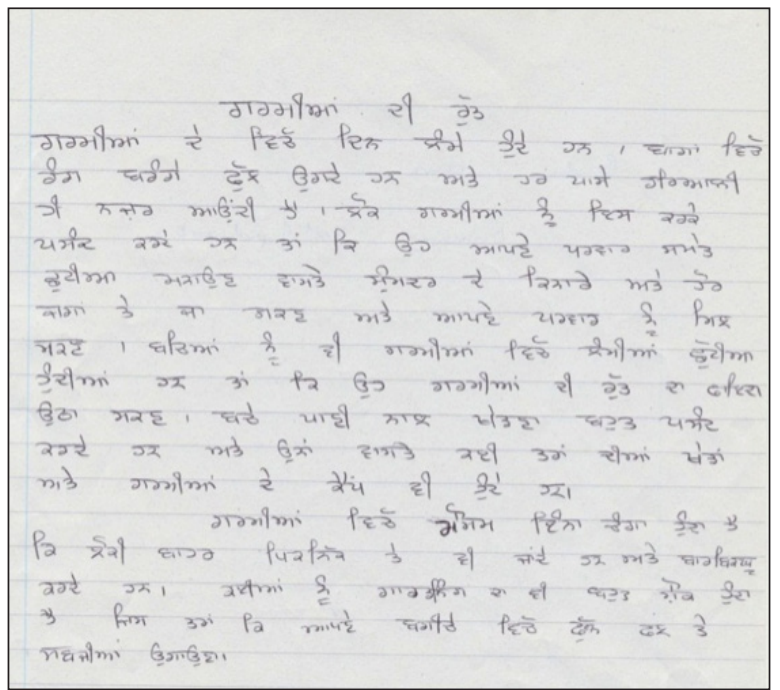


Figure 3. A plan for a recording on the topic of 'summer', in Punjabi http://languagebox.ac.uk/1779/

\begin{tabular}{|c|c|c|c|c|c|c|}
\hline \multirow{2}{*}{$\begin{array}{l}\text { Name: } \\
\text { Language(s) } \\
\text { taught: }\end{array}$} & \\
\hline & \multicolumn{6}{|l|}{ Punjabi } \\
\hline $\begin{array}{l}\text { Age(s) of } \\
\text { learners: }\end{array}$ & \multicolumn{6}{|l|}{$10-15$} \\
\hline $\begin{array}{l}\text { Level(s) of } \\
\text { learners: }\end{array}$ & \multicolumn{2}{|c|}{ Beginners } & $\begin{array}{l}\text { Xermediate } \\
\text { X }\end{array}$ & \multicolumn{2}{|c|}{ Advanced } & Mixed ability \\
\hline $\begin{array}{l}\text { Idea for } \\
\text { podcast(s): }\end{array}$ & \multicolumn{6}{|l|}{ Summer } \\
\hline \multicolumn{7}{|l|}{$\begin{array}{l}\text { What do you } \\
\text { need to create } \\
\text { your podcast? } \\
\text { (just you? } \\
\text { Music? Other } \\
\text { people? } \\
\text { Sounds?) }\end{array}$} \\
\hline $\begin{array}{l}\text { Language skill } \\
\text { that the podcast } \\
\text { supports: }\end{array}$ & Reading & Writing & $\begin{array}{l}\text { Speaking } \\
\mathrm{X}\end{array}$ & $\begin{array}{l}\text { Listening } \\
\mathrm{X}\end{array}$ & $\begin{array}{l}\text { Grammar } \\
\mathrm{X} \\
\end{array}$ & $\begin{array}{l}\text { Vocabulary } \\
\mathrm{X}\end{array}$ \\
\hline \multicolumn{7}{|l|}{ Keywords: } \\
\hline $\begin{array}{l}\text { Script for your } \\
\text { podcast } \\
\text { (continue on } \\
\text { other side): }\end{array}$ & \multicolumn{6}{|c|}{$\begin{array}{l}\text { Translation: } \\
\text { Summer has long sunny days. Summer is colourful as there are many different } \\
\text { colours of flowers and green all around. People like summer because they can } \\
\text { go on family trips to the beach and other places to visit like the countryside. } \\
\text { They also like to visit their families. Children have long summer holidays so they } \\
\text { can enjoy the hot weather. They love playing with water guns and having water } \\
\text { fights. There are lots of activities for children during their summer holidays. } \\
\text { Children enjoy going to funfairs and camping. People have lots of barbecues and } \\
\text { picnics because the weather is so nice. Some people like gardening and growing } \\
\text { flowers, fruit and vegetables. You can hear birds singing early in the morning. } \\
\text { Summer is an enjoyable season for everyone. }\end{array}$} \\
\hline
\end{tabular}

The final recording has been used in class by the teacher concerned, and LanguageBox statistics show that it has been viewed more than 350 times and downloaded 178 times. The teacher who produced it has learnt new skills and makes use of them in her current teaching. 
Figure 4. An audio recording on the topic of 'summer', in Punjabi, with accompanying files

http://languagebox.ac.uk/1779/

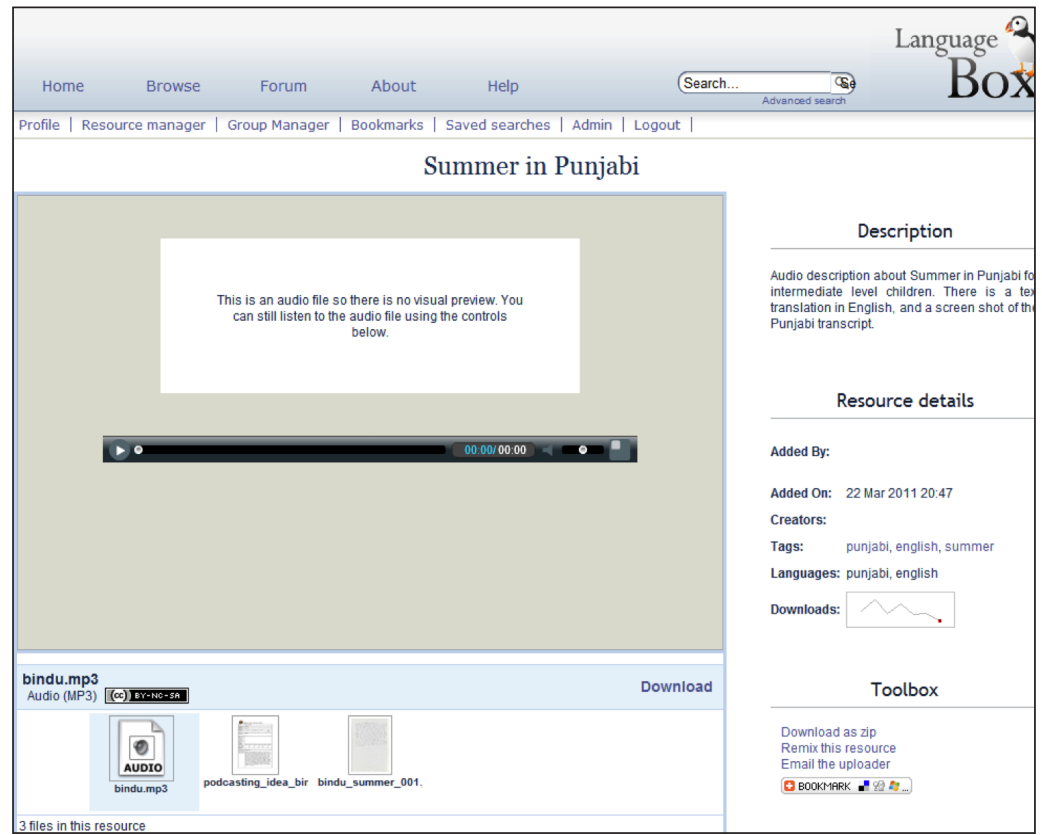

\subsection{Creating an online quiz/game}

The café session related to the creation of quizzes and games for language teaching involved discussion and consideration of how teachers use games and why they can be useful. The session concluded with the planning and preparation of a quiz which could then be put into free Hot Potatoes software to make an interactive online exercise. During the workshop, participants learnt how to use the free software Hot Potatoes, including how to change colours and insert images. Figure 5 and Figure 6 show an extract from the planning sheet which participants' used and one of the quizzes produced during the workshop. 
Figure 5. Planning sheet for creating an online quiz http://languagebox.ac.uk/1858/

\begin{tabular}{|c|c|c|c|c|}
\hline \multirow{2}{*}{\multicolumn{5}{|c|}{$\begin{array}{l}\text { Community Café Workshop Pack } \\
\text { Handout C4.4 } \\
\text { Quiz Planning Sheet }\end{array}$}} \\
\hline & & & & \\
\hline \multicolumn{5}{|c|}{\begin{tabular}{l|l} 
Topic: &
\end{tabular}} \\
\hline \multicolumn{5}{|l|}{ Title: } \\
\hline \multicolumn{5}{|l|}{ Question 1: } \\
\hline Answerchoices: & a) & b) & c) & d) \\
\hline \multicolumn{5}{|l|}{ Image (note link) } \\
\hline Feedback: & Correct Answer & & Incorrect A & \\
\hline \multicolumn{5}{|l|}{ Question 2: } \\
\hline Answer choices: & a) & b) & c) & d) \\
\hline Image (note link) & & & & \\
\hline
\end{tabular}

Figure 6. An online quiz for Punjabi produced as part of the workshop on creating online exercises http://languagebox.ac.uk/1778/

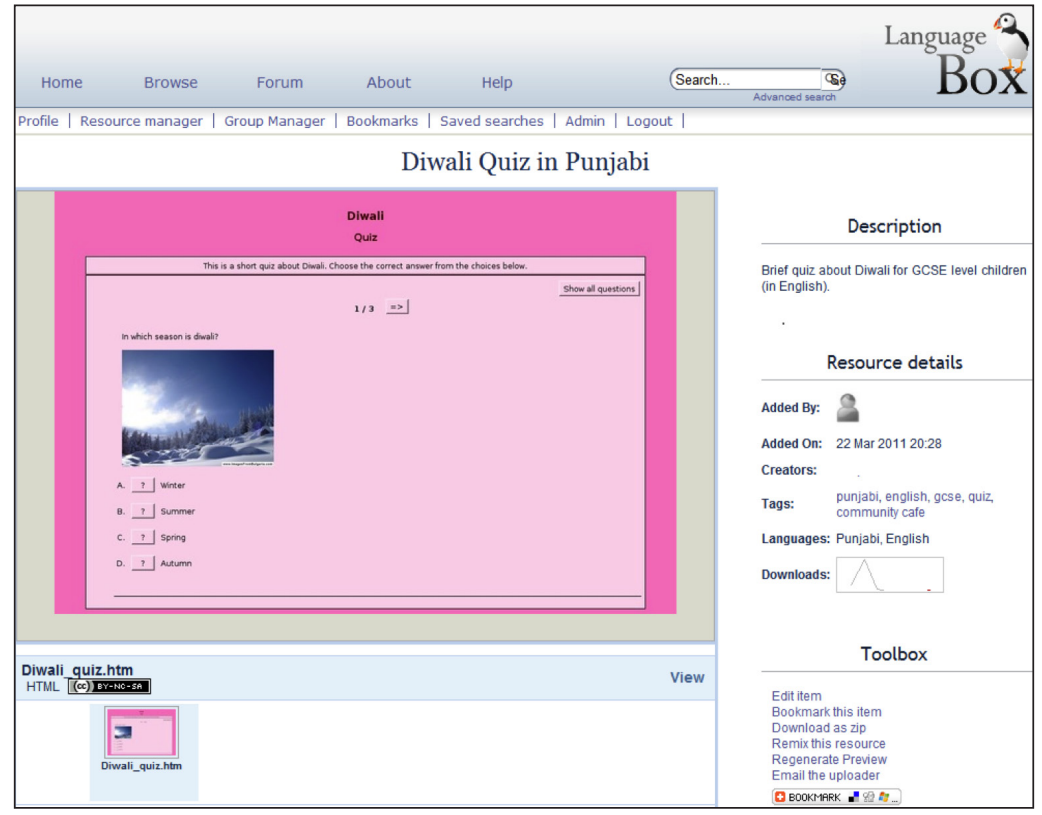


Figure 7 illustrates how all of the Community Café workshop activities could be combined into one interactive activity if participants had or learnt additional IT skills. This Hungarian resource includes 2 audio recordings and several online Hot Potatoes quizzes.

Figure 7. A Hungarian resource which has combined many of the workshop activities into one interactive learning object http://languagebox.ac.uk/1733/

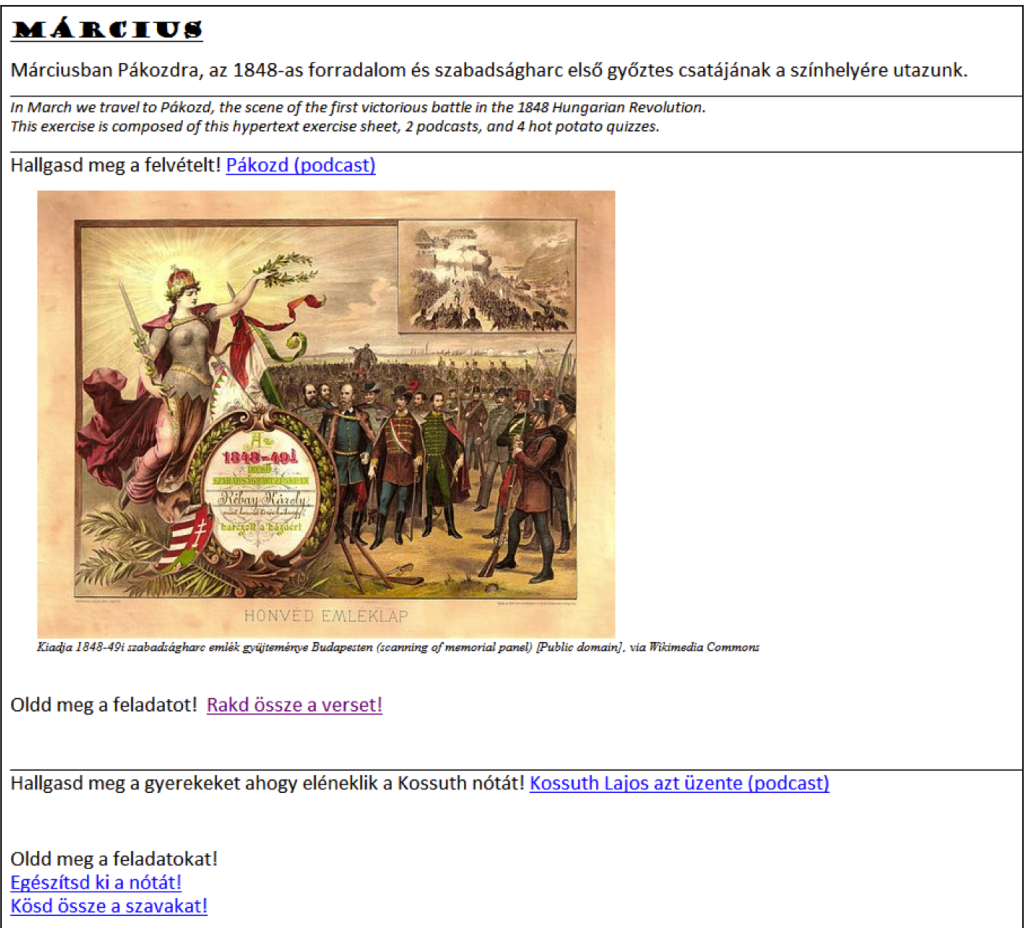

\section{Conclusion}

The impact of this short project on the community-based language teachers who took part was significant. They acquired new technical skills, made new 
contacts with colleagues, reflected on their teaching methods and resources, and learnt more about using the internet effectively to find resources and to publish their own work. The City Council officer who runs the network noted that: "tutors are already applying some of the things they have learnt in the classroom, and this has made a big difference to teaching quality". He felt that the project had "opened a new door for them [the tutors]". This demonstrates that creating and publishing open educational resources within a social, community setting has the potential to be a vehicle for the development and enhancement of professional skills, particularly for a group marginalised from mainstream education.

The social, collegiate aspects of open practice-sharing were important in this process, both online (via LanguageBox): "I have found the LanguageBox to be very useful as inspiration for my own lesson planning because I can get ideas from other teachers' lesson plans..." and offline: "Each teacher has different issues so it is interesting to hear different experiences. I have got some teaching ideas from other colleagues during café meetings". The benefits and challenges of sharing open resources amongst an identified community group is one aspect of open educational practice and sits alongside institutional and national initiatives in OEP and OERs. For example, within the UK, research work continues in this area at the Open University, with language teachers using the LORO repository, and at the University of Southampton, with general humanities practitioners using the HumBox repository.

OEP offers a flexible, low-cost means to share resources, share practice and increase the pool of teaching materials for community-based language teachers. These activities are much needed and valued by communitybased teachers, as shown by the number of downloads of project resources. Our short project revealed that tutors have great levels of enthusiasm for professional development and for open working, but it takes time to embed, absorb and act on new knowledge, and community-based teachers need continuing support and encouragement to help them access and build on ideas and experiences which may be commonplace to those in mainstream educational sectors. 


\section{Useful Links}

The entire Community Café workshop pack detailing including all facilitator/ teachers' notes, participant handouts and templates, plus instructions for setting up your own community café can be found at: http://languagebox.ac.uk/1846/

A reusable Language Game Dice was produced by the project as an open resource. This OER is accompanied by teachers' notes and is available at: http:/ languagebox.ac.uk/1835/

Journal article about the project:

Borthwick, K., \& Dickens, A. (2013). The Community Café: creating and sharing open educational resources with community-based language teachers. Journal of e-Learning and Knowledge Society, 9(1), 73-83. Retrieved from http://www.je-lks.org/ojs/index. php?journal=Je-LKS_EN\&page=article\&op=view\&path\%5B\%5D=803

CILT, The National Centre for Languages: http://www.cilt.org.uk/home.aspx

JISC: http://www.jisc.ac.uk/

JISC Community Café Project reports: http://www.jisc.ac.uk/whatwedo/programmes/ digitisation/communitycontent/communitycafe.aspx

Languages Open Resources Online: http://loro.open.ac.uk

Project blog: http://communitylanguages.wordpress.com/

The HumBox: http://humbox.ac.uk/

The LanguageBox: http://languagebox.ac.uk/ 